International Journal of English Literature and Social Sciences
Vol-6, Issue-5; Sep-Oct, 2021

Peer-Reviewed Journal

\title{
Socio-economic Status of Badi Women and Class Consciousness in Bibek Ojha's Ailani
}

\author{
Rudra Bahadur Charmakar
}

PhD Scholar \& Lecturer in English, Patan Multiple Campus, TU, Nepal

Received: 11 Sep 2021; Received in revised form: 01 Oct 2021; Accepted: 07 Oct 2021; Available online: 15 Oct 2021

C2021 The Author(s). Published by Infogain Publication. This is an open access article under the CC BY license

(https://creativecommons.org/licenses/by/4.0/).

\begin{abstract}
The research article deals with the socio-economic status of Badi community and consciousness in them. Basically, it critically analyses the content, context and plots of the text from the perspective of Marxist concept of class consciousness. The research explores that Badi community would not have any sources of regular income; so as, they were compelled to involve in prostitution few decades back. They would be exploited sexually by the then local feudal and clients; instead, they would get certain monetary wages and goods for their survivals. It also explored that the community would consider the profession (as sex workers) as their karma and dharma; and, nobody would prohibit them from involving in the profession. The caste system upon them was also rampant at that time; and, they were socioeconomically and politically oppressed, discriminated, exploited and prohibited from the social practices and public activities. The research shows the terrible and panic situation of Badi girls/women due to the multi-layers of exploitations based on the primary text Ailani by Bibek Ojha. The researcher employs the qualitative approach with exploratory method in the research.
\end{abstract}

Keywords-Exploitation, Class Consciousness, Caste System, Prostitution and Profession.

\section{INTRODUCTION/ RATIONALE}

Badi community is a minority group within Dalits of mid-western and far-western parts of Nepal. They have their own cultural practices and profession. Dalit Scholar Gopal Nepali (Badi) states "Badi community is the most backward minorities within Dalits; and,it is oppressed in economic, social, political, cultural and all aspects of society...The community would live mainly on the banksof rivers, streams and caves; and, would love to live as primitive life" (www.nagariknew.nagariknetwork.com). There are very few literatures related to this community available in the Nepali literary writings.

The research shows that there are two books/fictions published on Badi community- Nathiya by Saraswati Pratikshya and Ailani by Bibek Ojha. The novel Nathiya is focused on the nose ring opening system (nathiya) and the issues of sex-workers three decades back. The next novel Ailani is also focused on the exploitative feudal system and problems of sex-workers of the region. In fact, there are not conducted any research from the Marxist concept of class consciousness perspective yet. The present article aims to conduct the research from the concept of class consciousness based on the primary text Ailani (Public Land) by Bibek Ojha. The research adopts the qualitative approach with exploratory and analytical method.

\section{Objectives}

The main objectives of the research are to explore the socio-economic, cultural and political problems of Badi women; and to examine the class consciousness in them and their movements for dignified lives in the society.

\section{Methodology}

The researcher employs the qualitative approach and exploratory method based on the primary text Ailani. The theoretical framework is developed based on the Marxist concept of class consciousness by Georg Lukacs, Terry Eagleton, Robert Lanning, Erik Olin Wright and 
other Marxist scholars. The research is a type of content and critical discourse analysis from the above mentioned perspective.

\section{REVIEW OF LITERATURE}

The literatureson Dalit issues and subjects are available in Nepali literary writings. The Badi as Dalit community also includes the distinct issues of Dalits in their locations. Basically, Dalit literature is the socioeconomic, cultural, political and various other issues related to pains, sorrows, problems, protests, revolts and consciousness of Dalits and backward people. Dalit writer Ranendra Baraly's literature portrays the various aspects of Dalits' lives in the society. His most popular short story "Dalitko Dailo" depicts that how Dalits' skills and professions are exploited in the society. Dalits are artisans by their skills and occupations. They are true architectures of the society. In the story, a Dalit artisan named Kaile Kaami makes an artistic door with Gods' image and places it in the local temple but he is prohibited to enter the temple thereafter. The narration of the story reveals:

Oh, Kaile Dai, Is it an untouchable's temple? Do you want to enter the temple being an untouchable?

Kaile spoke, "I have made this statue myself. I have used my skill, labor and creativity; and, poured my sweat on it". And, he (Kaile) touched the statue of Shiva. But audiences announced that "Kaile Kami touched the temple! (Baraly "Dalitko Dailo" 20)

The pilgrims and the worshippers severely punish him in the accusation of touching the statue and entering into the temple.

Badi women are most vulnerable and exploited people of mid-western and far-western parts of Nepal. Saraswati Pratikshya's novel Nahiya depicts the nathiya (nose ring) opening system and socio-economic problems of Badi women of the far-western region of Nepal. In the novel, the protagonist Saamali Badi speaks when her nathiya is conspiratorially opened that "...Badiniki chhori hunu bhanyako aafu mattai dukhi hunu rahyachha. aafna karanle aru sappai khusi ra sukhi hunu rahyachha [...] to be a daughter of Badini is to be sad alone...other all are happy and fine because of me" (trans. Pratikshya 51). The assertion denotes that Badi women try to make their clients happy for their survival but they cannot be happy themselves.

Badi women have their own distinct problems regarding the profession and socio-economic lives. Some
Dalit literatures have analyzed the problems based on the novel Ailani. The novel is written by Bibek Ojha and published by Sangri-La Books, Kathmandu. Regarding the novel, Gopal Nepali (Badi) critiques that "the novel presents the essence as Badi women's bodies are like the non-registered public land (ailani)...the Badi woman's life is illegally compared to non-registered public land which can be used by anyone. The issues presented in the novel may negatively and psycho-socially affect to the new generation..." (nagariknews.nagariknetwork.com). The novel has affected to the dignity of the contemporary generation Badi women and girls because they have already quitted their profession few decades ago. In another context, Gopal Nepali remarks, "the word ailani alias non-registered public land reflects the Badi women's bodies as materials of public utilization" (www.soundcloud.com). The critics are not ready to accept with the presentation of the issues, contents, contexts and plots included in ailani and nathiya. The leaders and scholars of Badi community claim that the mal-practices of Badi cultures are already outdated in the society. Besides the above mentioned discussion, the research article looks at the Ailani novel from the concept of class consciousness.

\section{Socio-economic Problems, Class System and Class Consciousness in the Novel Ailani}

The novel Ailani (non-registered public land) by Bibek Ojha is a social novel. It is published by Sangri-La Books Publication Pvt. Ltd. in 2074 BS (2017 AD). It portrays the socio-economic problems, caste system, caste/class consciousness and movements done for rights, equality and dignity of Badi women. The plots setting of the novel takes place from Achham to Kailali districts (Hilly to Tarai/plain regions) of the far-western of Nepal. The novel revolves the love and relation of Basanti Badi and Amar; Fulmaya and Mukhiya; and, the main plot is narrated by the elderly woman Fulmaya based on her personal experiences and struggles of life from her childhood to adulthood days. Basanti is representative Badi girl of contemporary generation. The character, Amar is recently separated-man who is psychologically depressed; and moves to western Nepal to be refreshed and forget his wife Sharmila.The characters- Basanti and Amar meet in a bus travel. The novel reveals in the latter part that Fulmaya is step-grandmother of Basanti and they live in Muda, Kailali district. The love between Basanti and Amar and love and life-story of Fulmaya flow simultaneously in the novel. The novel also portrays multiple-problems and paradigms of Badi women's lives; and shows their consciousness through movements for rights, equality, dignity and social justice. 
The caste system is still rampant in most parts of Nepal. Most of the people matter the caste and community at the very first sight of their meet. When they see the person and attract towards him/her; and they start thinking about their castes and communities. This seems so embarrassing to the strangers. In the novel, Ailani, the character Amar who has psychological problem; introduces tothe character Basanti, who is very beautiful girl. The narrator asks:

\section{khair, sodheko thiyan, "kun jaatki hou?"}

u akaichhin mouna basi. Bahirapatti herirahi. sochiholi 'kina surumai jaat sodhyo?' aafailai pani sodhen- 'kina maile jaat sodhen?"..

ali dhilai vaye pani sahajai jawaf farkayi, 'ma badi jaatki hun."

lakh katen- 'yo pani yahi dhanda garchhe holi."

[Finally, I had asked, "which caste do you belong to?"

She kept quiet for some time. She kept on looking outside. She might think "Why did he ask my caste at first? I asked myself as well- "Why did I ask her?"...

Lately, she replied easily, "I belong to Badi caste."..

I assumed- She might involve in prostitution!"] (trans. Ojha 09)

Perhaps the narrator belongs to so-called upper caste of the society; because he never reveals about his caste in the novel. He thinks about her caste and profession immediately. It is considered as a form of discrimination and exploitation. In this connection, Erik Olin Wright regards the form of exploitation as "privileged appropriation location within exploitation" (92). It does not seem as exploitation; but the location, time, context and audience of the dialogue denote it as a form of exploitation.

The social relation is exploitative and discriminatory in varna-based society. The relation does not seem equal because it is age-old relation. The literature presents the realistic picture of inequality of the people of the society. The Russian critic Georgy Plekhanov states "The social mentality of an age is conditioned by that age's social relations. This is nowhere quite as evident as in the history of art and literature..." (qtd. in Eagleton 5). As in the novel, social relations between characters seem diverse. The unequal relation between so-called lower and upper castes seems exploitative and discriminatory. In the story, Fulmaya who lives with Basanti's family narrates her own story which depicts the panic situation of Badi women as:

kehi dinpachhi aamoi ra ma mukhiyako ghar garyou...paaripattiko ukalo chalda maile aamoilai sikayau, "aamoi mastai chamal magnu hai"

"Huchha. tara, kya garnu, bhat khan ka sajilo chha ra? kasakasa dhanimuni ta bhat khan sakdainan"

"Mukhiya pani sakdainan?"

[After some days, I and my mother went to Mukhiya's house...I taught (requested) to mother when we were walking to next hill, "Mother, please, do request for more rice".

"Sure. But what to do, it is not easy to have rice-meal. Many rich people also cannot have rice-meal"

"Does not Mukhya have rice-meal?" (trans. Ojha 19)

In the society, there is economic disparity even between/amongst the upper-caste people. They do not have quality and healthy foods due to their economic status. Badi women who are socio-economically backward and poor cannot join their hands every morning and evening easily. Fulmaya in the story, as daughter of Badi, expects quality and hygienic foods from her mother but her mother cannot provide easily.

The feudal society exploits the poor/working class people and Badi women every day. Moreover, exploitation to Badi women is more severe. It is not only the sexual exploitation but wage/work exploitation. To quote Erik Olin Wright, as "...the concept of economic rent is irrelevant to class analysis, but simply that it has more complex relationship to the problems of exploitation" (89-90). The working class people cannot defend against. In the novel, the local feudal embarrasses the Badi girl Fulmaya when she is fourteen. The novel narrates as:

farkidai garda mukhiyale mero sharirbhari aankha dulay. gahiriyara mera abodh aankhama here. shirdekhi pausamma niyale. ule tyasari herda man kasto anoutho gari ramayo. jhanai ujjyali bhai unlai niyale. mero bare kura samet gare. "thuli bhaisakyaki raichha".

Aamoile muskuraudai mero umer batayin, "sahib, chaudhaki matrai bhai". 
Mukhiyale tauko hallayara. bhane, "prajatantra aayaka saal janmyaki raichhha".

[When we were about to return, Mukhiya looked at my body. He looked at my eyes deeply. He looked at me from head to feet. I was excited when he looked at me. I looked at him with cheerful face. He remarked about me, "She is already adult".

Mother told my age with smile, "Your lord, she is only fourteen".

Mukhya waved the head. Said, "Perhaps, she was born in the year of democracy"]. (trans. Ojha 21)

The Badi girls, in the novel, are not safe from the local feudal and the clients from non-Dalits. The story covers the setting of about six decades back; butthe situation is slightly different now. However, Badi women and girls are still struggling for their dignity and social respect. Mukhiya is very much curious about the age of Fulmaya. Though, Fulmaya's step-father enunciates that her face is similar to Mukhiya. Fulmaya's mother knows that she was pregnant when she had first sex with Mukhiya after her first mensuration but she could not share it to Mukhiya or anyone. From this angle, Fulmayamay be his blood or own daughter; but Mukhiya is not ready to accept; rather, nonDalits blame that Badi children have no true fathers at all.

It is true that the socio-economic exploitation is a product of political mal-practices. The politics guides the overall practices and systems of the society. The relation between the Badi people and the non-Dalits is discriminatory; but the unbalanced relation is already acceptable for Badi. It is considered that a feudal is already set organization of the society. It is not easily breakable in real sense. In this connection, Robert Lanning, in his book Georg Lukacs and Organization Class Consciousness states, "The political form of organization that set them on this route was developed in part from the people most immediately victimized by exploitation and racism" (20). The exploitation and racism are practiced in the form of set organization. In the novel Ailani, Fulmaya's mother who is about double-aged than Fulmaya, is rejected by the clients but they are attracted to Fulmaya instead. She is just fourteen years old. Mukhiya of the village is already attracted to Fulmaya that she is considered as the daughter of the Mukhiya according to the information of Fulmaya's mother. The narrator reveals as:

uso ta pesha samhalnu galat lageko thiyana. tyo hamro karma ra dharma jasto lagthyo, jasari pujapath garnu bahunko karma ra dharma hunchha. tara pani malai khai kina darle agalyo...bhane, "aaja nai bhana aamoi. unlai bholi bolao. mu voli pakka daraunna."...

mu bas sikaudai chhu jiunya meso. baghle aafna bachchalai sikar garna sikauchha...

Mukhiyale mamathi kehi shabda kharchiya, "Fulmaya! tan asadhyai ramri chhai"...

Mukhiyale aafno trisna mete. ma bastu thiya kyar. malai aamoile bhanejasto majja lagena...

[So far, I didn't think to start the profession. It was our karma and dharma; as Brahmin commences his karma and dharma by ritual processions. But, I don't know why I was afraid of...

Well, I will teach you the way to live. The tiger teaches how to find the food...

Mukhiya described about me with few words, "Fulmaya! You are so beautiful...

Mukhiya fulfilled his desire. I was just the living-corpse (object). I did not feel interesting as my mother had told me"] (trans. Ojha 28- 32).

In the novel, the mother forces to start the profession as sex-worker to her daughter, Fulmaya; and the clients like local feudal, Mukhiya exploits her by appreciating her extreme beauty. They both are exploited. But, Fulmaya considers it as the profession or karma and dharma of Badi girls and women. From the perspective of Marxism, Fulmaya is exploited as worker of the society. The social system is discriminatory and exploitative towards the workers and Badi girls and women of the then society. The poor girl Fulmaya is convinced with tasty food and materials; and, she is exploited brutally.

The women characters presented in the novel are like living materials or objects to sell and use. The materials are as public property. Anyone can use them easily. Basanti is a teen-age-girl; she has to involve in prostitution for survival now; and, Fulmaya is also compelled to involve in the profession when she was fourteen. Both characters represent the Badi girls of different generations, are struggling for joining their hands to mouths. Unfortunately, Fulmaya becomes pregnant in the age of seventeen due the continuous sexual exploitation by local feudal, Mukhya; but Mukhya is not ready to give the status of his wife because the society is there to boycott Mukhiya, his family and Fulmaya. In the novel, Fulmaya narrates: 
bastabma mero petma baseko bachcha mukhiyako ragat thiyo. tyehi mukhiyako ragat nai mukhiyabata tadhinuparne karan bandai thiyo. bachcha baseko bhanda mukhiyasanga chhuttinu parne darle badhi dukheki thiyan ma. unibata tadha hunu kalpanabhanda kosou tadhako bishaya thiyo...tyo bela jaane, ma mukhiyalai asimit prem garna thalisakeko rahechhu...ba, aamoi ra samajaka lagi mero samasya thulo thiyan. [The baby which was in my worm was the blood of Mukhiya, in fact. Mukhiya's blood was being a reason to be separated from him. I was worrier to be separated from Mukhiya than to be pregnant. It was out of my imagination to be separated from him... I knew that I had started loving to Mukhiya so much...but my problem was not a big deal for my step-father, mother and society]. (trans. Ojha 71).

The love, tragedy and marriage for Badi girls are regarded as a common issue in the society. Fulmaya is exploited continuously and become pregnant but it is her obligation that she has to do the profession for her family. She knows that she is exploited but she cannot protest easily at the beginning. It is connected to economy for the family. In this regards, Georg Lukacs argues, "...class interests in pre-capitalist society never achieve full (economic) articulation" (55). The economic domination or poverty stops the voices against the suppressors. In Badi community, if the girls are pregnant from non-Dalit clients, the parents and the society find the husbands from Badi community; but the marriages will be for formality they do not have permanent living relations.

Every love relation is tied with trust and commitment. Mukhiya's relation is temporary based on the attraction with the beauty of teen-age-girl. But Fulmaya is completely in deep relation with him; though, it is onesided love for Mukhiya. She ignores all. She is not ready to get married to any other person; because she never wants to be far from him. When Fulmaya becomes pregnant, her parents find a Badi boy from the settlement but she does not want to get married with him; rather, she becomes sad. She wants to play with nature and forgets herself. On the way back to home, she is attacked by a group of people and defended and escaped from there which is turning point of the story. Mukhiya takes her to his home as the plot reveals:

...laamo swas fere, "Fulmaya mu tera manko kura panda sakdaina. taile nabhani mu kya jaanu?"
Oho...! tyaspachhi ma aafaile soche bhanda farak bhayan. nitanta farak. runa chahanathe tara parela naaghera aanshu aayihale. angaalu sochera unlai angaaleko thiyina. tara, haatharu aafase aaf salbalaya. jor lagai angale. unko chhatima chyapiya. chahera daako chhodeki thiyina. tara kantha jorle bajigayo. antata: ma jorjorle runa puge....

unle mero pitthu thapthapaya. kehi ber runa diya...rudarudai thak lagyo. ruwai shithil hudai gayo bistarai...

[He took a long breath, "Fulmaya, I cannot read your heart and feelings. How can I know it, if you don't say?" Oho...! After then, I found different than my thinking. Absolutely different! I did not want to weep but tears appeared crossing my eyelaces. I did not embrace him with intension. But, my hands unknowingly moved towards him. I embraced him tightly. I was embraced on his chest. I was not crying loudly intentionally. But, throat sounded loudly. At last, I cried loudly...

He patted on my back. He let me weep for some time. I was tired of weeping. The weeping was slowly lethargic...] (trans. Ojha 82)

From the assertion of the novel, it denotes that Fulmaya loves to Mukhiya from the bottom of her heart. She cannot live without him but it is thoughtful that Mukhiya already has family, the society and the relatives; so that, he cannot give company easily. Ultimately, he gives company shortly. He fights with the family, relatives and the society; and keep Fulmaya in a separate home known as raatoghar (Red Home) but slowly Mukhiya becomes old; leaves his married wife; becomes alone and falls in sick. The story reveals that he is too old to be become healthy; finally, Fulmaya escapes from the raatoghar and moves to Terai from Achham with her mother and neighbors. Unfortunately, her mother and neighboring aunt are missed while crossing the river. Thereafter, Fulmaya and Basanti's own mother become helpless; and they have been living there in Muda, Kailali for years thereafter.

Liberation from the feudalistic and capitalistic society is a dream of proletariats. In the novel, Fulmaya liberates from her feudal Mukhiya by escaping from his red home. In this regards, referring to Georg Lukacs, Robert Lanning remarks, "His identification of subject and object in the proletariat was in part grounded in the belief that in liberating itself the proletariat would liberate 
humanity because it was the only class not interested in its own continuation, but this implied an inherent relationship between the proletariat's liberation and human freedom" (43). Fulmaya's liberation is the liberation from the exploitation and the feudalistic society. Mukhiya makes her anillicit wife (rakhel) because he does not give her a true social identity as a status of wife, respect, freedom and right of inherent property. She is socially, physically and economically exploited for decades as she lives an imprisoned life for more than a decade. So, her decision to liberate from there is considered a good decision. It is consciousness to be liberating from bourgeoisie in Marxist term. Erik Olin Wright, in the context argues, "Marx's view of the role of ideological mystification in preventing class organization and the importance of class consciousness intellectual leadership in raising working class consciousness, a theme stressed in different ways..." (38). In the novel, Fulmaya's action and effort seem a consciousness of the working class people to be liberating from the exploitations.

The society believes that the system is constructed and sustained by the god or almighty power. Badi people believe that they are made backward and discriminated due to their caste and culture. But, Basanti, a young and conscious girl of present generation is not ready to accept it. She blames to the society, the traditional mind-set and the economic status of Badi; so that, they are backward. Sorensen argues, "...a result of the development of class consciousness creates class conflict" (qtd. in Wright 80). Fulmaya and Basanti, both characters struggle against the social concept and practices. In the novel, Basanti has many turning points in life. She does not believe in the God but she reads the holy books for knowledge and entertainment. Basanti argues to Amar as:

ma astik hun!

ma nastic hun!

ma astik hun!

ma nastic hun!...

uso bhaya timi kina mahabharat padhiraheki? yo to hinduharuko mahangrantha ho"

....yo kitabka tyo samayaka ghatanaharu jarur huna sakchhan tara yo kitab pujnuko karan dekhdina. yo granthabhitra dukhka sagarharu chhan. ke dukhaharu pujnayogya chhan?

[I am theist!

I am atheist!

I am theist!
I am atheist!

If so, why are you studying the Mahabharata? This is a great epic of Hindus?

...the book may include the incidents of the then time but I do not see it as worshipful book. The epic has oceans of sorrows. Are sorrows the worshipful?] (trans. Ojha 46- 47)

Basanti raises the question regarding the worshipfulness of the holy books of Hindus because the holy books are the collections of sorrows, pains, curses and deaths of thousand warriors; and these are not necessarily worshipful books. She clams herself as atheist. The pain, sorrow, discrimination and exploitation of the Badi girls have erased the respect towards religious beliefs and values.

The realization of exploitation and discrimination raise the conflict in society. The continuous and routinely discrimination is the main reason of the revolt. The consciousness ultimately sees the need of class conflict in the society. In this connection, Istvan Meszaros remarks, "Proletarian class consciousness is, therefore, the worker's consciousness of his social being as embedded in the necessary structural antagonism of capitalist society, in contrast to the contingency of group consciousness which perceives only a more or less limited part of the global confrontation" (101). The workers' consciousness against the capitalist society raises the issues of rights, equality and dignity of workers in the society. The character Basanti asks many questions regarding her castes as, "ke ma manchhe hoina? kunai sambegma testo lagchha. kunai sambegma aafaidekhi pani ta aaudaha hunchha, ghrina hunchha [Am I not a human? In some moments I feel so. In some moments, I feel absolute sad, and I feel hatred myself"] (trans. Ojha 44). The feeling of being a human is a consciousness in the working class people. It bears the value of life. The Badi women's movement centered in Singhdurbar Gate in 2007/2008 AD is the consequences of their obsolete consciousness raised in their minds.

The proletariats or working class people cannot join their hands every morning and evening without works and professions. They have to work for their survival. In the novel, Basanti works in a hotel when her mother is sick. She has to manage the budget for her mother's treatment. But she cannot get her salary/wage easily. She narrates as "tara sahib! madhuro bandai gayo mero jindagi. kinaki, maile pasinako mol paaun saahuko pauma asmita pokhnu paryo. kahilai saahusanga nasuti aafno jyala payina...ma dherai chotile chithoridai gaya...tehi dinbata maile hotel chhodidiya [But your lord! My life is 
being deemed. I had to sleep with hotel owner to get my wages. I never get my wages without sleeping with hotel owner... I had been scratched many times...from that day; I quitted the job of hotel] (trans. Ojha 147). The exploitation of laborers' wages is the main problem of capitalism. In this context, Robert Lanning argues about exploitation that "...complexities of exploitation in system of stratification, and attempted to measure the possibilities more efficiently with a social division of far more than the basic number of classes..." (26). The exploitation brings the complexities and conflicts between masters and workers. In the novel, Basanti revolts against the hotel owner and leaves the job; rather, she involves in prostitution because the socio-economic problems and the society oblige her to involve in the profession. In Robert Lanning's understanding, "...the development of class consciousness must begin before the working class can reasonably expect to attain power, means that this goal cannot be left to evolutionary development" (2). The revolt of Basanti is for self-dignity and satisfaction. She openly says that she becomes the contact-sex-worker because the government has prohibited the prostitution. The government has also made some agreement to address the issues and problems of Badi women and to settle them with respectable professions.

Badi girls and women have multiple-layers of problems related to caste, culture, profession and their economy. Basanti is a single daughter of her mother whose mother is deaf due to the side effect of malaria. She has an adopted-grandmother, Fulmaya. She has to bear the responsibility of three people but her family does not have any other income sources. The society and the state do not provide them any job and work in which they do have dignified lives in the society. As a result, she is compelled work as a sex-worker which is illegal profession according to the laws. The narrator reveals as:

timibhanda dusman ta yo bhok ho. bhok nabhaidiya jaati hunthyo. timisanga gunaso thiyana. $k$ timi hamro bhok hour a? sahib, bhok ma manis ke bandaiana? batho manis chor banchha. baliyo manchhe daaka banchha. bhokma haami jasta machhe ochhyan banchhau. jasko sharir pani bikdaina, uniharu bhikhari banchhan. jasale bhikh magna jandaina, uniharu bhokle marchhan. bastabma jindagi bhikle nai nirdharan gardorahechha [Hunger is the enemy, rather, you. It would be better, if there was not hunger in us. There would not be any complain on you. Are you our hunger? Your lord! What would be a man in hunger? If he is clever; he becomes thief. If he is strong; he becomes robber. But, we became beds in hunger. Those who do not have strong bodies; they become beggars. Who cannot beg; they die of hunger. The life is determined by the hunger, in fact. (trans. Ojha 198)

The economy determines the status of life of every person in the society. Every Badi woman's life is terrible due to her poverty, caste and lack of consciousness. To quote, Wright as, "...the most important intellectual obstacle to class consciousness: the belief in the naturalness and permanency of the existing conditions and thus the impossibility of any fundamental change" (39). People know that what is wrong and what is right but they cannot do as per their consciousness and understanding because there is something other factor which determines all the actions, efforts and our profession that is related to economy. The entire society is compelled to follow the rule of economic system. Because of it, they cannot achieve any fundamental change in their socio-economic lives.

The characters of the novel are very much conscious about their socio-economic positions. However, they cannot change their profession due to lack of alternative income sources. Basanti's mother expresses to a writer about the panic lives of Badi women. She says about the daughter Basanti that "socheki thiya chhorilai jiu bechna dinna. schoolma first aauthi. tara mero sano biramle usle thulo umer dhannu paryo. aba usko padai bigrisakyo...usle sanaima dherai patak sodheki thiyi, "Bhagwan chhan ki chhaina?" maile tettinai patak sunayaki thiyan, "sayad chhaina. chhan bhane sahebkai najik baschhan" [I had thought that I would not let the daughter sell her body. She was first girl in her class. But my common illness made her to survive as an adult life. Now, her study is already disturbed... She had asked me many times in her early age, "Is there an existence of the God?" I had replied her many times, "Perhaps, not. If he exists, he might be near to you, my lord...] (trans. Ojha 198- 199). Basanti is not only a beautiful girl but she is also a talented one. But her economic crisis compels her to be a sex-worker in the society. Regarding it, Robert Lanning argues, "...class consciousness as specifically related to human development and politically motivated action, dislodging consciousness from the specific context of capitalism as the essential structure through which classes are formed" (7- 8). The class consciousness is motivated by actions, social structure and capitalistic system where the working class people live in. Basanti's main problem is connected to her caste, poverty and social belonging. 
Economy is the fundamental need of social life. People cannot survive without it. In the novel, Basanti is a representative character of Badi girls and women who is involved in illegal profession due to poverty and other family problems. A writer who is close to Basanti's mother writes about the seemingly common but very notable problems of Badi women who are obliged to involve in the profession which is prohibited by the open society and the state. After reading the pages written by a writer which discloses the realistic problems of Badi girls and women, Amar consoles to Basanti in the novel as:

abadekhi timiharulai khana ma
kinidinchhu. ma padaidinchhu schoolma. u
khulla tabarle muskurai, "sahib malai kehi
chahinna. aba jindagima euta sapana
matra jiudo chha. ma bihe garera eutai
manchhesanga jindagi katna chahanchhu.
eutai manchhelai prem garirahana
chahanchhu jindagibhar. ek samanya
jindagi bachna man chha. [Today on ward,
I will buy the foods for you. I will manage
the budget for your study. She openly
smiles, "My lord! I don't need anything. I
have only one dream remained to my life. I
want to live rest of my life with a single
man. I want to love a man throughout my
life. I want to live a normal life]. (trans.
Ojha 200)

The above mentioned assertion shows the dream of a representative Badi girl; who does not have a big dream but she wants a normal life where she can get social respect and dignity. Basanti is a representative character who has dream to get married and love to a single man to whom she can pass her entire life. Her consciousness is that her profession is not good enough in the society; rather, she wants to liberate her from the pitfall of problems and illegal profession. Regarding the class consciousness, Robert Lanning further argues, "...class and class consciousness is that it exists in a complex of relations, it is not simply designation of place or position in economic production" (9). The class consciousness issue is not only connected to economic production, position and place but it is a complex issue. It is the issue of social domination, exploitation, dignity and justice.

The working class people like Badi girls want to get freedom and dignity; so that, they feel an eternal happiness and satisfaction in their lives. In the novel, Amar as narrator of the plot expresses, "usko kura samanya thiyo. sundar thiyo. u pani sundar lagi. yasto lagyo basantika aakhale malai khojiraheka chhan. ulse feri thapi, yadi timro prem chhaina bhane ma banchhu timro prem. biswas gara mero premlai akaalma marna dinechhaina. timi premkai karan birami baneko hou tyo premkai karan niko hunechha [Her statement was common. It was beautiful. She was also beautiful. I felt, Basanti's eyes were searching to me. She further added, "If you do not have love (beloved), I will be your love. Trust me; I will never let my love die early. You became sick due to love; you will be fine due to my love."] (trans. Ojha 200). Basanti's propose to Amar is clear and direct that she wants to live and die with Amar. She wants to live a dignified but normal life with her life partner. Robert Lanning, in this context, argues, "...developing consciousness are the counterproductive, regressive analyses (explored later) that effectively disorganize the consciousness of the working class and the means by which class consciousness is developed" (23).

In the novel, Fulmaya feels before leaving raatoghar (Red house) as "aafnai biswas lagna chhadyo malai. jindagi ek khelouna na rahechha. prem tyasakai ek bhag lagyo. jindagika dinharu farkifarki chihayan. Jahan manle samarpit premmathi aula uthayo. ma chupchap aafna harek pailalai ghrina gardai hiddai thiyan. jiwanko mulya pani...! [I could not trust myself. Life is a commodity (toy). Love is just a part of it. I looked back to the bygone days; where my mind raised the question to my die-heart love. I walked over every step silently with hatred. And, value of life...] (trans. Ojha 262- 263). She clearly awakens from the deep illusion of love and escapes from there. It is rejection of everything which is worthless in life. In this context, Bertell Ollman remarks, "the development of class consciousness is a potential "rooted in a situation unfolding before our eyes, long before the understanding of real people catches up with it"" (157). Fulmaya and Basanti both open the eyes of consciousness and liberate them and their society. The novel ends with opening the plot that the story is yet to be started because the love and relation between Basanti and Amar is yet to be revealed.

\section{CONCLUSION}

The novel Ailani by Bibek Ojha mainly portrays socio-economic and cultural problems of Badi girls and women of far-western part of Nepal. Badi community as Dalit minority group of Nepal has been socially boycotted, economically poor and backward, politically excluded and educationally illiterate people of Nepal. The community would be regarded as entertainer; but they would make musical instruments (madal, dhol etc.), weave the fishing net, do fishing, and make smoking pipe. However, the profession would not enough for their survival; as a result the community involved in prostitution (sex workers) for local feudal of the society. The novel has covered the 
stories from 1940s to 2000s. The Badi girls and women would make happy to the local feudal, non-Dalits and clients by providing their bodies; instead, they would get money, materials, grains, clothes and other daily using goods. The novel reveals multiple-layers of socioeconomic problems that how the feudalistic society would oppress and exploit Badi girls and women brutally in those days. Badi community were fighting with extreme poverty; so that, they were compelled to provide their bodies for those males. The novel is the life-struggle stories of Fulmaya, her generation and Basanti, Laxmi and other Badi girls of third generation.

Time, context, and society are changed; Fulmaya and her generation would directly sell their bodies in the society; but Basanti, Laxmi and other Badi girls of the present generation are not allowed to do prostitution legally. But, their socio-economic status has not drastically changed. They are still fighting with poverty because they do not have any regular income sources for survival. So, they still involve in prostitution in hotels, rooms and other secret places. The novel basically reflects the Badi girls and women's problems, socio-economic problems and caste consciousness of three generations.

\section{ACKNOWLEDGEMENTS}

I would like to thank to the University Grants Commission (UGC), Nepal for the PhD Fellowship and Research support. I would also express my thanks to Prof. Dr. Krishna Chandra Sharma, Prof. Dr. Abhi N. Subedi and Dr. Shiv Rijal for their guidance.

\section{REFERENCES}

[1] Baraly, Ranendra. "Dalitko Dailo". Dalitko Dailo. Lalitpur: Sajha Prakashan, 2068 BS. Print

[2] Eagleton, Terry. Eagleton: Marxism and Literary Criticism. London: Routledge Classics, 2002. Print

[3] Lanning, Robert. Georg Lukacs and Organizing Class Consciousness. Minneapolis: MEP Publications, 2009. Print

[4] Lukacs, Georg. History and Class Consciousness. trans. Rodney Livingstone. London: Marlin Press and New Delhi: Parrot Reads Publishers, 1971. Print

[5] Mészáros, Istvan. "Contingent and Necessary Class Consciousness".Aspects of History and Class Consciousness.ed. Istvan Mészáros, London: Routledge \& Kegan Paul, 1971. pp. 85-127.

[6] Nepali (Badi), Gopal. "Badi Samudayko Asahamati Kina?" $\begin{array}{llll}\text { NAGARIK DAINIK. } & 24 & \text { Saun, } & 2075\end{array}$ https://nagariknews.nagariknetwork.com/news/54368/

[7] "Nathiya ra Ailani Biruddha Kanuni Upacharko Prakriyama Jaane Badi Samudayako Udghosh"
SOUNDCLOUD https://soundcloud.com/user575373075/audio/

[8] Ojha, Bibek. Ailani. Kathmandu: Sangri-La Books Pvt. Ltd., 2074 BS. Print

[9] Ollman, Bertell. Dialectical Investigations. New York: Routledge, 1993. Print

[10] Pratiksha, Saraswoti. Nathiya. Kathmandu: Book-Hill, 2074 BS. Print.

[11] Wright, Erik Olin. Understanding Class. London: Verso, 2015. Print 